\title{
Международная научно-практическая конференция «Ползуновские чтения - 2018» в Барнауле
} еждународная научно-практическая конференция «Ползуновские чтения - 2018» состоялась 12-13 декабря 2018 г. в Барнауле в Алтайском государственном техническом университете им. И. И. Ползунова (в дальнейшем АлтГТУ). Данная конференция, на протяжении многих лет традиционно проводившаяся в АлтГТУ и объединявшая всех заинтересованных лиц, была посвящена жизни и деятельности выдающегося изобретателя и создателя первого в мире пароатмосферного двигателя для приведения в действие заводских механизмов Ивана Ивановича Ползунова, имя которого носит университет.

Организаторами проведения конференции выступили Алтайский государственный технический университет им. И.И. Ползунова, Гуманитарный факультет, Кафедра истории Отечества.

В работе конференции приняли участие ученые, преподаватели, сотрудники музеев и библиотек Казахстана (Усть-Каменогорск, Темиртау), Польши (Торунь), России. Конференция явилась прекрасной возможностью представить результаты своих исследований, обменяться мнениями по различным вопросам, укрепить наметившиеся контакты и заложить новые, обсудить перспективы дальнейшего сотрудничества.

Пленарное заседание 12 декабря открыло выступление профессора Карагандинского государственного индустриального университе- 
та 3.С. Гельмановой (Темиртау Казахстан) «Современные подходы к управлению вузом». Яркий, живой, иллюстративный доклад профессора вызвал огромный интерес у аудитории.

Затем с докладами выступили:

- профессор АлтГТУ Б.А. Сосновский «Проблемы психологии на производстве»;

- заведующий кафедрой философии, профессор АлтГТУ В.Ю. Инговатов «Философия техники в антропологическом измерении»;

- доцент АлтГТУ О.Е. Контева «Формирование территории горно-металлургического комплекса на юге Западной Сибири в XVIII в.»;

- доцент АлтГТУ В.В. Исаев «Производственная и научно-техническая деятельность И.И. Ползунова в горнозаводской промышленности Алтая в XVIII в.»;

- научный сотрудник Алтайского государственного краеведческого музея С.В. Головеева «Мурзинская горная крепь как памятник истории горнорудного дела на Алтае» (Барнаул, Россия).

Все представленные доклады вызвали неподдельный интерес у присутствующих и сопровождались подробным обсуждением.

13 декабря работа конференции осуществлялась по трем секциям:

1. Культурное наследие И.И. Ползунова. Развитие инженерной мысли в России и за рубежом.

2. Исторические аспекты исследований.

3. Новые коммуникативные технологии в образовании: психология, педагогика, лингвистика.

Среди выступавших результаты своих исследований представили:

- научный сотрудник И.Б. Каланчина «Печатные издания XIX начала XX вв. как источник изучения движения переселения в Сибирь» (Централизованная библиотечная система имени Оралхана Бокея, Усть-Каменогорск, Казахстан);

- архивариус И.В. Дурново «Из истории народного образования в Усть-Каменогорском уезде в 1920-е гг. по документам ГАВКО» (Восточно-Казахстанский областной архитектурно-этнографический и природно-ландшафтный музей-заповедник, УстьКаменогорск, Казахстан);

- доцент О.В. Степанова «Известные врачи Алтая: из истории становления специализированных служб здравоохранения на Алтае в XX в.» (АлтГТУ, Барнаул, Россия). 
- доцент Л.Н. Лихацкая «Живописный портрет XVIII в. в собрании Государственного Художественного музея Алтайского края» (АлтГТУ, Барнаул, Россия).

По ходу выступлений у присутствующих в ряде случаев возникали вопросы, происходил обмен мнениями.

Особый интерес вызвали выступления профессоров В. Резмера (Университет Н. Коперника, Торунь, Польша) и заведующей кафедрой истории Отечества И.Н. Никулиной (АлтГТУ, Барнаул, Россия), осветивших основные направления участия поляков в научных исследованиях Сибири XIX-XX вв., доцента Т.А. Аскалоновой «Истоки горнозаводского производства на Алтае» (АлтГТУ, Барнаул, Россия). Принявшие участие в обсуждении профессор Л.Н. Лукин (АлтГТУ, Барнаул, Россия), заведующая кафедрой «Обработка металлов давлением» Карагандинского государственного индустриального университета О.Н. Кривцова (Темиртау, Казахстан) отмечали важность данной тематики и необходимость выявления новых интересных подробностей жизни и деятельности И.И. Ползунова.

Во время работы конференции ее участникам была предложена экскурсия по историческим местам Барнаула. Желающие могли посетить музей АлтГТУ, выставку картин «Поэзия пленэра» художницы И. Леденевой в Центре культуры АлтГТУ, фонд редких книг Алтайской краевой универсальной научной библиотеки им. В.Я. Шишкова, выставку архивных документов Государственного архива Алтайского края.

Все доклады участников конференции будут опубликованы в сборнике материалов, с которыми смогут ознакомиться все желающие. 
